\title{
The Behavior of Australian Banks' Capital Buffers: Pro- or Counter-Cyclical?
}

\author{
$\mathrm{Ha} \mathrm{Vu}^{1} \&$ Sean Turnell ${ }^{1}$ \\ ${ }^{1}$ Economics Department, Macquarie University, North Ryde 2109, NSW, Australia. \\ Correspondence: Ha Vu, Economics Department, Macquarie University, North Ryde 2109, NSW, Australia
}

Received: December 18, 2014

Accepted: January 9, 2015

Available online: January 27, 2015

doi:10.11114/aef.v2i1.654

URL: http://dx.doi.org/10.11114/aef.v2i1.654

\begin{abstract}
This paper investigates the behavior of capital buffers of Australian banks to changes in the business cycle. More particularly, whether there is a behavioral difference between big and small banks, and whether the 2008-09 global financial crisis influenced bank behavior with respect to capital buffers. Applying the Generalized Method of Moments technique, we find the evidence to support pro-cyclical behavior of large banks, but counter-cyclical of small banks. Our results also show that banks with large size, large risky portfolio, and high lending growth rate tend to hold less capital than their peers. Finally, our results suggest that the latest financial crisis did induce banks to hold more capital.
\end{abstract}

Keywords: Australia, Business cycle, Capital buffers, Capital regulation, financial crisis.

\section{Introduction}

The 2008-09 global financial crisis has prompted market participants, regulators and rating agencies to reappraise the appropriate levels and forms of capital that banks should hold to deal with potential losses during economic downturns. As a result of these efforts, banks in a number of countries, including Australia, have come to maintain capital buffers above the regulatory minimum as a cushion to avoid financial distress and absorb losses in the case of turmoils. A capital buffer can be identified as the extra capital banks hold on top of the regulatory minimum. In Australia, banks are required to hold total capital of at least $8 \%$ of their risk-weighted assets, in which total capital is the sum of Tier 1 (including ordinary shares and retained earnings, which make up most of the Tier 1 capital held by Australian banks, as well as some specific types of preference shares and convertible securities) and Tier 2 (predominantly consisting of subordinated debts) capital.

The reasons why banks may hold capital beyond the minimum required level have been explained elsewhere in the banking literature. Firstly, banks generally tend to assess their risks differently from regulators. For instance, they are likely to use their own internal economic capital models to estimate appropriate bank-specific capital levels to hold, given their own assumptions and risk appetites (Jackson, 1999). Secondly, banks might need to hold excess capital in order to signal soundness to the market and satisfy the expectations of rating agencies. Thirdly, holding a capital buffer may bring advantages of future 'growth opportunities'. For instance, if facing a substantial increase in demand for loans, banks with relatively little capital may lose market share to those that are well capitalized (Jokipii \& Milne, 2008). Finally, holding capital more than required by regulators may induce banks to screen and monitor borrowers more carefully (especially in the case that a bank cannot completely diversity risk in its loan portfolio - a key feature of banking in developing countries), thus the repayment probability tends to increase, which in turn leads to a lower cost of borrowing for businesses and households (Agenor, Alper, \& Pereira da Silva, 2012).

The relationship between bank capital buffers and the business cycle can go in either direction. Proponents of the idea that the link is primarily pro-cycle argue that banks tend to increase their capital buffers during upswings beyond what current risk fundamentals suggest. This accumulation of capital might be because banks take into account the possibility that risks may actually increase during upturns, and internalize the negative externalities of pro-cyclical requirements on macroeconomic stability (Ayuso, Pérez, \& Saurina, 2004). On the other hand, advocates of counter-cyclicality believe that during booms banks tend to underestimate actual risk (i.e., in expanding credit) and they fail to appropriately judge the cyclical nature of output.

The dependence of capital buffers on the business cycle may have a negative impact on macroeconomic stability. In theory, in the wake of losses, a bank can restore its capital ratio by either going to the market and raising fresh capital, 
or leaving its capital unchanged and shrinking its asset base. However, ordinarily it is difficult for banks to raise capital during a bust. If a bank chooses to shrink its assets (e.g., by cutting back on lending), others can pick up the slack, which means market share is transferred from weaker and troubled institutions to their stronger peers. Nevertheless, if a large fraction of the financial system is in difficulty, a simultaneous attempt by many institutions to shrink their assets is likely to be more damaging still to the economy more broadly.

Furthermore, capital buffers could provide an important macro-prudential instrument for monetary authorities and could help to stabilize the economy. Increasing bank capital requirements during upswings may have the secondary effect of moderating excessive credit growth and thus taking some of the 'heat' out of an economic expansion. Similarly, reducing capital buffer requirements when economic and financial conditions are pessimistic might help relieve restraints on lending and keep monetary policy effective.

The majority of the literature in this field has reported the existence of counter-cyclical behavior of bank capital, indicating they reduced their capital buffers during booms to take opportunities of good economic environment (see, for example, Ayuso et al., 2004 for Spanish banks; Marcucci \& Quagliariello, 2008 for Italian banks; Stoltz \& Wedow, 2011 for German banks; Francis \& Osborne, 2012 for UK bank; Guidara, Lai, Soumaré, \& Tchana, 2013 for Canadian banks). Several cross-countries studies also report the same results. For instance, Chen and Hsu (2013) examining the behavior of bank capital in 171 developed and developing countries found that the capital buffers will decrease by $0.142 \%$ when GDP growth rate rises by $1 \%$. Similarly, an adverse relationship between capital buffers and the business cycle was shown by Bikker and Metzemaker (2005) analyzing the bank capital buffers of 29 OECD countries, and Fonseca and Gonzalez (2010) investigating the determinants of bank capital buffers in 70 countries.

The Basel Committee of Banking Supervision (BCBS) has set out a new global regulatory framework (commonly known as Basel III) for more resilient banks and banking systems. In particular, Basel III has introduced a new countercyclical capital buffer component which imposes a range of $0-2.5 \%$ of a bank's risk-weighted assets to be levied on top of the revised capital adequacy requirements. The main objective of these countercyclical capital buffers is to achieve the broader macroprudential goal of protecting banking sectors from taking on too much systemic risk as a result of excess credit growth (BCBS, 2010). The Australian Prudential Regulation Authority (APRA) has adopted the minimum Basel III capital requirements, in full, from 1 January 2013. ${ }^{1}$ However, APRA does not include a requirement for a countercyclical capital buffer. The findings in this paper might offer some implications regarding this issue.

It is of our interest to examine whether different types of banks (i.e., large versus small) behave differently when it comes to capital holdings. Jokipii and Milne (2008) report that capital buffers of large banks seem to fall during good times and rise during bad times, while capital buffers of small banks co-move positively with the business cycle. They explain the possible reason for this being that it is more costly for smaller banks to raise new capital, thus they rely more on retained earnings as a cushion against insolvency and illiquidity. Accordingly, they build up more capital buffers during economic expansion. Furthermore, because it costs more for smaller banks to borrow in the wholesale debt market, they are more dependent on deposits as a source of funding. Thus, it seems more difficult for them to respond to cyclical increases in loan demand than larger banks. In contrast, Guidara er al (2013), focusing on six largest Canadian banks, find that these banks have a larger capital buffer in expansion and in recession.

This paper adds to the existing literature in two ways. Firstly, it adds another piece of empirical evidence to the literature which currently flooded with studies of capital buffers of EU banks, US banks, and elsewhere rather than in Australia. Secondly, the paper examines the effect of the latest financial crisis on the behavior of bank capital buffers. This allows us to predict the impact of shocks and risk appetite of Australian banks.

The remainder of the paper is structured as follows. Section II describes the methodology, while Section III explains the definitions of the variables. Section IV analyses the empirical findings, and Section V presents the conclusions.

\section{Methodology}

To test whether bank capital buffers change over the economic cycle or not we follow the methodology proposed by Ayuso et al. (2004) and Estrella (2004). We use a partial adjustment framework in which bank $i$ seeks to attain its optimal capital buffer $B U F_{i, t}^{*}$ given its observed capital buffer at time $t-1, B U F_{i, t-1}$ :

\footnotetext{
1 According to APRA's proposal, all Australian authorized deposit-taking institutions (ADIs) will have to meet the requirements of $4.5 \%$ of common equity capital to risk-weighted assets (increased from $2 \%$ under Basel II), $6.0 \%$ of Tier 1 capital ratio (increased from $4 \%$ under Basel II), and an $8 \%$ total capital ratio (which is the same as under Basel II). In addition, from 1 January 2016, ADIs are required to hold an additional $2.5 \%$ of common equity Tier 1 capital (known as a capital conservation buffer), thus raising the minimum common equity Tier 1 ratio to $7 \%$.
} 


$$
\Delta B U F_{i, t}=\delta\left(B U F_{i, t}^{*}-B U F_{i, t-1}\right)+\varepsilon_{i, t}
$$

where $\Delta B U F_{i, t}\left(=B U F_{i, t}-B U F_{i, t-1}\right)$ represents the observed change in capital buffers between two consecutive periods. Capital buffers (BUF) are defined as the difference between the capital to risk-weighted assets ratio the bank holds and the regulatory minimum (for the period under examination, $8 \%$ ) required by APRA. $\delta$ represents adjustment costs of the actual capital buffer toward its optimal level.

In the absence of adjustment costs, then $\delta=0$, and from equation (1) it follows that $B U F_{i, t}=B U F_{i, t}^{*}$. This implies that banks can pick up any level of capital and move directly to its optimal level. In this case, banks would not hold extra capital rather than that required by law or by the markets. This situation happens if deposits are completely insured, depositors have no incentives to monitor bank shareholders and they accept a risk-free rate regardless of the risk to deposits. Accordingly, the optimal choice for banks is to hold the maximum amount of debt, and bank capital only varies in response to changes in risk-weighted assets (Fonseca \& González, 2010). At the other extreme, when $\delta=1$ the model implies $B U F_{i, t}=B U F_{i, t-1}$, suggesting that transaction costs are so large that the bank is stuck with the same capital ratio that it had at the beginning of the period. Thus, in the presence of high adjustment costs banks may not be able to change their desired capital buffers instantly via either equity issues or reducing assets. While the former option may convey negative information to the market on the bank's economic value, the latter may require a bank to sacrifice positive net present value projects or to sell assets at prices below their values. The tradeoff between the cost of holding capital and the cost of failure determines the optimum capital buffers (Shim, 2013).

Equation (1) can be rewritten as:

$$
B U F_{i, t}=\delta B U F_{i, t}^{*}+(1-\delta) B U F_{i, t-1}+\varepsilon_{i, t}
$$

Although the optimal capital buffer is unobservable, it depends on the stage of the business cycle, as well as bank-specific factors (Jopikii and Milne, 2008; and Stolz and Wedow, 2011). Therefore the estimated model is specified as follows:

$$
B U F_{i, t}=\lambda_{1} B U F_{i, t-1}+\lambda_{2} C Y C L E_{t}+X_{i, t}^{\prime} \beta+\varepsilon_{i, t}
$$

where $C Y C L E_{t}$ is a measure of the business cycle at time $\mathrm{t}$ and is proxied by the growth rate of real GDP; $X_{i, t}$ is a vector of bank-specific variables for bank i at time $\mathrm{t}$, including bank size, risk, liquidity, profitability and lending growth.

Technically, the estimation of Equation (3) may face several economic problems: (i) bank-specific variables may not be strictly exogenous, suggesting that causality might run in both directions, for instance from risk to capital buffers and vice versa, thus these regressors may be correlated with past and possibly current realization of the error; (ii) the presence of a lagged dependent variable $B U F_{i, t-1}$ gives rise to autocorrelation; and (iii) fixed individual effects may be correlated with the explanatory variables. The fixed effects are contained in the error term $\varepsilon_{i, t}$, which includes the unobservable bank-specific effects, $u_{i}$, and the observable specific error, $v_{i, t}$ (i.e., $\varepsilon_{i, t}=u_{i}+v_{i, t}$ ), where $v_{i, t}$ is assumed to be independent and identically distributed with zero mean. Therefore, to overcome these problems we employ the GMM approach suggested by Blundell and Bond (1998) to estimate Equation (3). This approach is superior to the conventional OLS in addressing potential endogeneity, heteroskedasticity, and autocorrelation problems in the 
data.

\section{Data and Variables}

The studied sample consists of 13 Australian banks over the period from 1993 to 2011. All data were collected from individual bank annual reports. Due to availability issues and mergers and acquisition activity, not all banks have the necessary data over the studied period. Thus there are 185 observations altogether. As noted earlier, in this paper a capital buffer $(B U F)$ is defined as the deviation of the observed capital ratio of an individual bank in each year from the regulatory minimum level of capital of $8 \%$. Our data for the sample period shows that Australian banks hold far more prudential capital than required by APRA. It was 3.85\% on average over the sample period (as reported in Table 2). This fashion of large capital buffers have been found for US and EU banks (see Peura \& Jokivuolle, 2004; Jokipii \& Milne, 2008).

Following the literature, the business cycle is proxied by real GDP growth. A negative relationship between GDP growth and capital buffers would reflect risk-sensitive behavior. However, in case a positive relationship is found, it would reflect forward-looking and prudent behavior by reserving more in 'fat' years to use in lean years.

Figure 1 shows the evolution of the average capital buffers of the Australian banking sector and real GDP growth rates since 1993. There seems to have a negative relationship between capital buffers and the business cycle. In fact, the Pearson correlation coefficient between the two variables is -0.17 and significant. It is also worth noting that capital buffers rose quite dramatically since the onset of the GFC.

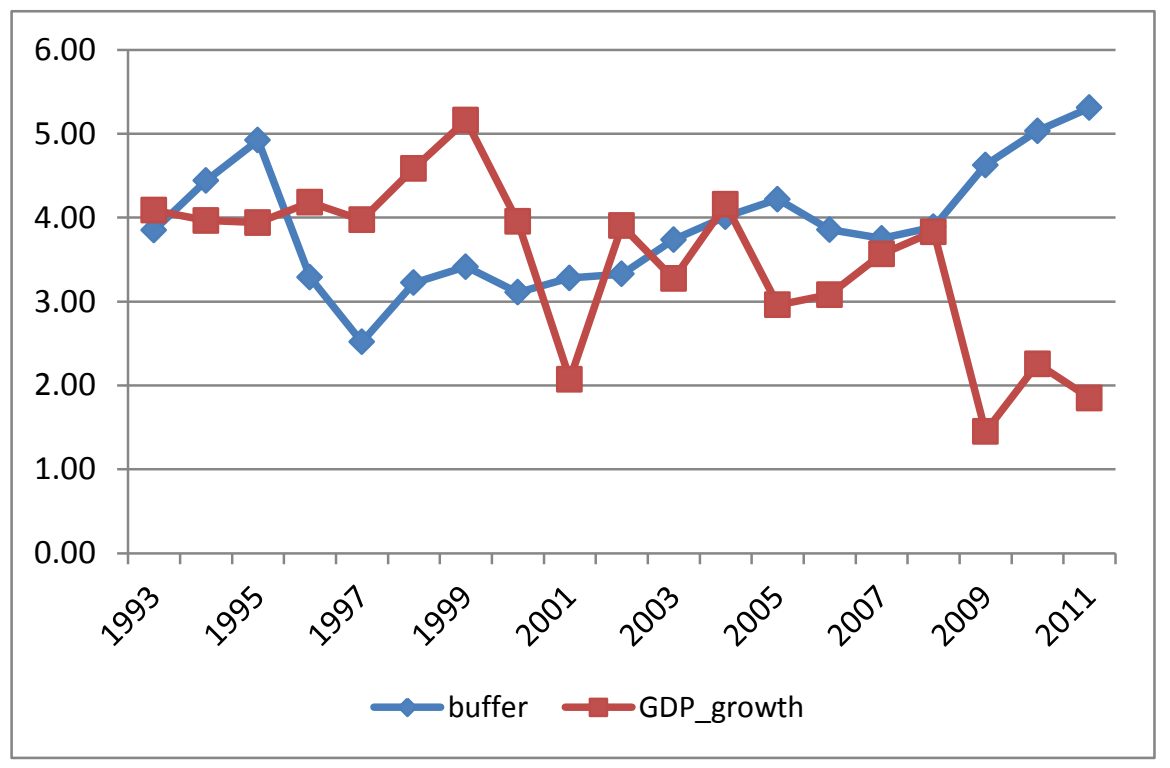

Figure 1. Bank Capital Buffers and GDP Growth

The level of a bank's capital buffer may depend on a number of bank-specific attributes, including bank size, asset risk, liquidity, profitability, and lending growth.

As adopted widely in the literature, the natural logarithm of an individual bank's total assets is used as a proxy for bank size (SIZE). Big banks normally hold smaller capital buffers than small banks. This could be because large banks may enjoy more investment and diversification opportunities, more resilient to negative shocks, and thus don't need as large capital buffers as insurance against shocks. In addition, there is a common expectation (a "too big to fail" belief) that big banks will be bailed out by governments when they face financial distress. Francis and Osborne (2012) and Coffinet, Coudert, Pop, and Pouvelle (2012) found a negative relationship between bank size and capital ratios in the UK and French banking sectors respectively, implying that larger banks tend to hold relatively lower capital ratios on average.

Bank risk (RISK) could be quantified by alternative measures such as the probability of default, value at risk, net loan loss provisions and write-downs over total assets, non-performing over total loans, or risk-weighted assets to total assets ratio. The last metric is commonly used to characterize the risk profile of bank assets and credit risk. The underlying principle for using this proxy, as explained by Shim (2013), is that the allocation of assets across different risk categories, which are assigned a weight to reflect the actual credit risk and to determine a bank's portfolio risk. Moreover, as Australian banks focus on traditional lending activities, credit risk is the most significant risk. Accordingly, we employ the ratio of risk-weighted assets to total assets as a measure of bank risk. 
Liquidity (LIQUID) is measured by liquid assets (including cash at banks, money at short call, securities purchased under agreements to resell, bills receivable and remittances in transit) as a ratio of total assets. As banks with high liquidity have a greater ability to meet short time financial obligations, and can increase their capital buffers by liquidating these assets, they need less insurance against a possible violation of the minimum capital requirement (Stolz $\&$ Wedow, 2011). As a result, it is expected that the estimated parameter associated with LIQUID has a negative sign.

Bank profitability is measured by expressing operating profit after tax as a ratio of book equity (ROE). Capital can be raised through the capital markets by issuing new equity or through retained earnings. The former is very costly, that is why banks normally use retained profit to raise capital buffers. Thus the relationship between profitability and capital buffers is expected to be positive, as indeed, is normally found in the literature (see, for instance, Coffinet et al., 2012).

Annual loan growth (LOANG) is measured by the growth rate of credit demand between two consecutive years. A high lending rate would raise total assets relative to capital, and thus lower the capital buffer (Jokipii \& Milne, 2008).

It is, of course, also our intention to investigate the effect of bank size in the behavior of capital buffers over the business cycle, and whether the response of capital buffers to changes in the business cycle is more pronounced for big banks than for small banks. INTERACT is the multiplicative dummy of SIZE (a dummy equals to 1 for large banks, and 0 otherwise) and GDP (a growth rate of GDP). ${ }^{2}$ If the coefficients on CYCLE and INTERACT are both negative (and significant), capital buffers of large banks react more intensively to changes in the business cycle. In other words, a $1 \%$ increase in the annual growth rate of GDP leads to a larger reduction of capital buffers for large banks than for small banks. This could happen because big banks have better access to equity markets than small banks, and thus can lower capital buffers during upswings without facing a high level of risk, while small banks do not have that opportunity.

Furthermore, we are concerned whether the global financial crisis in 2008-2009 influenced the behavior of banks in Australia with respect to capital buffers. In particular, whether banks in Australia hold more capital after the crisis. A dummy GFC is equal to 1 if year is 2008 and onward, and 0 otherwise. It is expected that GFC has a positive sign.

The definition of all variables in use is summarized in Table 1, while their descriptive statistics are displayed in Table 2. It is noteworthy that banks in Australia hold an average prudential capital ratio of 3.85\% higher than the level required by the regulators, and given the gradually upward trend its high standard deviation suggests a significant differentiation of capital buffers across banks. For this fact, we assess whether the evolution of capital buffers over the business cycle would vary with bank size.

Table 1. Definition of Variables

\begin{tabular}{ll}
\hline & Definition \\
\hline BUF & Observed capital to risk-weighted assets ratio minus 8\% \\
SIZE & Natural log of total assets \\
RISK & Risk-weighted assets to total assets ratio \\
LIQUID & Liquid assets to total assets ratio \\
ROE & Annual net profit before tax to average equity \\
LOANG & Annual loan growth rate \\
CYCLE & Annual real GDP growth rate \\
INTERACT & The multiplicative dummy of LARGE (a dummy equals to 1 for four big banks, and 0 otherwise) and \\
& GDP \\
GFC & Equal 1 if year is after 2007; otherwise 0 \\
\hline
\end{tabular}

Table 2. Summary Statistics (1993-2011, 199 Observations)

\begin{tabular}{lcccc}
\hline & Mean & St.dev & Minimum & Maximum \\
\hline BUF & 3.85 & 2.32 & 0.70 & 13.40 \\
SIZE & 10.23 & 2.33 & 5.27 & 13.53 \\
RISK & 58.47 & 14.68 & 27.07 & 94.48 \\
LIQUID & 2.57 & 2.67 & 0.05 & 18.14 \\
ROE & 14.95 & 5.54 & -0.56 & 28.10 \\
LOANG & 12.46 & 11.69 & -12.00 & 62.87 \\
CYCLE & 3.37 & 0.99 & 1.45 & 5.16 \\
INTERACT & 1.31 & 1.79 & 0.00 & 5.16 \\
GFC & 0.25 & 0.43 & 0.00 & 1.00 \\
\hline
\end{tabular}

Table 3 presents the correlation coefficients between the variables used in the model. It is important to firstly notice that

\footnotetext{
${ }^{2}$ In this paper, four major banks (including Commonwealth, ANZ, National Australia Bank, and Westpac) are considered as large banks, and other banks are small ones.
} 
among those significant correlations at 5\% (marked with an asterisk), there is no highly correlated relationship. As expected, capital buffers are negatively correlated with real GDP growth (-0.17), bank size (-0.39), and risk (-0.19). Likewise, there is a positive correlation of GDP growth with loan growth, the ratio of returns to equity, and the ratio of risk-weighted assets to total assets. These suggest that banks grant more loans, make higher profit, and turn toward riskier assets in upturns.

Table 3. Correlation Matrix

\begin{tabular}{|c|c|c|c|c|c|c|c|c|}
\hline & BUF & SIZE & RISK & LIQUID & ROE & LOANC & CYCLE & NTERACT GFC \\
\hline BUF & 1.00 & & & & & & & \\
\hline SIZE & $-0.39 *$ & $=1.00$ & & & & & & \\
\hline RISK & $-0.19^{*}$ & -0.06 & 1.00 & & & & & \\
\hline LIQUID & 0.12 & -0.06 & 0.03 & 1.00 & & & & \\
\hline ROE & -0.10 & $0.39 *$ & 0.08 & 0.02 & 1.00 & & & \\
\hline LOANG & -0.30 & -0.03 & -0.02 & 0.07 & $0.25^{*}$ & 1.00 & & \\
\hline CYCLE & $-0.17 *$ & -0.08 & $0.27^{*}$ & $-0.15^{*}$ & $0.30^{*}$ & $0.21 *$ & 1.00 & \\
\hline INTERACT & $\Gamma-0.43 *$ & $0.67 *$ & $0.33^{*}$ & -0.09 & $0.24^{*}$ & -0.06 & $0.27^{*}$ & 1.00 \\
\hline GFC & $0.22 *$ & 0.11 & $-0.31 *$ & $0.15^{*}$ & $-0.35^{*}$ & $-0.24^{*}$ & $-0.60^{*}$ & $-0.17 *$ \\
\hline
\end{tabular}

\section{Empirical Findings}

The estimated results are presents in Table 4. It is worthwhile to note that, with a high p-value in the Sargan test, the null hypothesis that over-identifying restrictions are valid is not rejected. Furthermore, the Arellano - Bond test rejects the null hypothesis of no first-order autocorrelations, AR(1), in the residuals. This is attuned with the fact that the dynamic model has the first lag of the endogenous variable as one of the regressors. However, the null hypothesis of no second-order autocorrelation, $\operatorname{AR}(2)$, is not rejected, indicating that there is autocorrelation in levels. These tests signify that valid instruments are being used and the dynamic model is well specified.

Table 4. GMM estimates, equation in first differences; Dependent: BUF

\begin{tabular}{llc}
\hline & Coefficient & t-value \\
\hline BUF(t-1) & $0.37^{* * *}$ & 4.36 \\
SIZE & $-0.80^{* * *}$ & -2.71 \\
RISK & $-0.09^{* * *}$ & -4.13 \\
LIQUID & -0.4 & -0.66 \\
ROE & 0.03 & 1.21 \\
LOANG & $-0.02^{*}$ & -1.91 \\
CYCLE & $-0.31^{* *}$ & -2.61 \\
INTERACT & $0.41^{* *}$ & 2.14 \\
GFC & $0.55^{*}$ & 1.77 \\
\hline Sargan test & Chi2 $=115.00$ & p-value $=0.54$ \\
AR(1) & $\mathrm{z}$-value $=-6.12$ & p-value $=0.00$ \\
AR(2) & $\mathrm{z}$-value $=0.43$ & p-value $=0.66$ \\
\hline
\end{tabular}

Note: $\operatorname{AR}(1)$ and $\mathrm{AR}(2)$ represent first and second order residual autocorrelation test;

$*, * *, * *$ denote significance at the $10,5,1 \%$ levels of significance respectively.

The coefficients of CYCLE and INTERACT are negatively and positively significant at 5\% respectively, implying capital buffers of small banks respond negatively to changes in the business cycle, while those of big banks respond positively. ${ }^{3}$ More specifically, a $1 \%$ increase in GDP growth leads to an average decrease of 0.31 percentage points in small banks' capital buffers, while it leads to an increase of $0.10(-0.31+0.41)$ percentage points of large banks'. In other words, big banks behave pro-cyclical, while smaller banks counter-cyclical.

To trace out a plausible explanation for this heterogeneous result we need to look into insight changes of the components of capital buffers, namely bank capital (the sum of tier 1 and tier 2 capital) and risk-weighted assets. It

${ }^{3}$ We also examine if there is a commonly negative relationship between the business cycle and capital buffers of the Australian banking sector by dropping INTERACT. And we find that the coefficient on CYCLE is insignificant. 
appears that during economic expansion, to make use of investment opportunities, both small and big banks draw down their capital level and just maintain enough to meet the regulatory requirement. Notably capital holdings of small banks falls at a faster rate $(0.017 \%)$ compared to those of bigger banks $(0.01 \%)$ for each $1 \%$ increase in GDP growth rate. Meanwhile, the risk-weighted assets of small banks swell slightly, while those of large banks shrink $0.014 \%$ per $1 \%$ increase in GDP. As a result, capital buffers of small banks decline, while capital buffers of large banks expand during upturns. In fact, large banks in Australia are accredited to use an Internal Ratings Based (IRB) approach whereby risk weights are derived from their own estimates of each exposure's probability of default, thus they can revise IRB risk estimates to reflect riskiness in each period. ${ }^{4}$ Hence they adjust the risk weights to lower their risk-weighted assets during good times, leading to a slightly increase in capital buffers. It is noteworthy that, like their smaller counterparts, big banks also draw down their capital level during economic expansion to take advantage of investment and lending opportunities. Regulatory authorities should take into account this practice in the implementation of counter-cyclical capital buffer requirement.

This interesting finding is in contrast with the one obtained by Jopikii and Milne (2008), who found that capital buffers of large banks in the EU15 behave counter- cyclically with the cycle and capital buffers of small banks behave pro-cyclically. In another study, García-Suaza, Gómez-González, Pabón and Tenjo-Galarza (2012) found that capital buffers of Colombian banks behave counter-cyclically, and capital buffers of large banks respond more intensively to changes in the business cycle than those of small banks.

The statistically significant and relatively large coefficient on the lagged buffer shows the high degree of persistence in these capital buffers over the studied period. This finding supports the view that the costs of capital adjustment are an important explanation of the holding of large capital buffers (Jokipii \& Milne, 2008).

As regards to bank-specific variables, the estimation results show that the coefficient for bank size is highly significant and negative, indicating that larger banks tend to hold lower capital buffers than their smaller counterparts. In fact, the average capital buffer of large banks during the study period was $2.56 \%$ compared to $4.64 \%$ for small banks. As explained by Stoltz and Wedow (2011), there are a number of ways to explain for this distinction in bank capital buffers due to bank size. First, banks' operation efficiency is subject to asymmetric information which could be quite costly, thus they need to hold excessive capital to deal with any possible insolvent situations in addition to the practices of screening and monitoring reduce the asymmetry. If there are economies of scale in screening and monitoring, large banks should hold relatively less capital and instead undertake more monitoring and screening. Second, larger banks may have better investment and diversification opportunities. Thus, they are subject to a lower probability of a large negative shock to their capital and only need to hold a lower capital buffer as insurance against such a shock. Third, as evident in the real world, big banks will receive greater support from the government (such as financial bailout) when facing financial hardship (Shim, 2013). This finding is broadly in line with previous studies, including Stoltz and Wedow (2011), Garcia-Suaza et al. (2012), Francis and Osborne (2012), and Coffinet et al. (2012).

RISK is significant and negative (although the scale is quite small) suggesting that risky banks possess smaller capital buffers. It is commonly expected in the banking literature that the risk level and bank capital holdings are positively correlated, meaning riskier banks would hold higher capital. Australian banks do follow this practice. However, their risk-weighted assets rise at a faster rate than their capital level do, the ratio of capital to the risk-weighted assets would fall and so do capital buffers.

The coefficient LIQUID is negative but insignificant, implying that it is not certain that banks with a greater proportion of liquid assets embrace smaller or larger capital buffers. ${ }^{5}$ Similarly, the estimated coefficient ROE has the expected sign (i.e., positive) but is not significant, hence a bank's profitability has no influence on the direction of capital buffers even though banks might use retained profits to increase the capital cushion. To verify the unimportant effect of profitability on capital buffers, we employed the return to assets ratio (ROA) instead of ROE and obtained the same result. This finding is somewhat consistent with the fact the issuance of new equity and other forms of securities to raise capital account for around 70\% of Tier 1 capital of Australian banks, while the remaining 30\% from retained earnings (Gorajek \& Turner, 2010).

The coefficient LOANG is negatively significant, showing that a bank's loan growth influences change in capital

\footnotetext{
${ }^{4}$ Other banks use the standardized approach which specifies risk-weights for certain loans types.

${ }^{5}$ Stolz and Wedow (2011) found an unexpected positive effect of liquidity on capital buffers. They explained this effect could be due to the fact that their liquidity measure includes share and bond holdings, thus banks hold capital buffers in order to provide for corresponding market risk.
} 
buffers. That is, a $1 \%$ increase in the lending growth rate will lead to a fall of 0.02 percentage points in capital buffers on average. This can be explained by the fact that significant lending growth tends to increase risk-weighted assets, which in turn lowers the capital- assets ratio.

Lastly, as predicted, the coefficient on GFC is positively significant, indicating that the 2008-09 financial crisis has had a large impact on the evolution of capital buffers. More specifically, the average capital buffer after the post-crisis period is $0.54 \%$ higher than the pre-crisis one. As explained in Gorajek and Turner (2010), the rise in capital in the Australian banking system post-GFC mostly reflects the large amount of new equity - the highest quality form of capital - that was issued in late 2008 and up to the middle of 2009, mainly through a combination of new share issuance and dividend reinvestment plans. The new share issues were at only modest discounts to the market price and were entirely to the private sector. There was no injection of public money into Australian banks. In addition, the raising of capital was also via increases in retained earnings via solid profits throughout the crisis. On the other hand, in response to the change in global attitudes, Australian banks adopted a more cautious growth and composition strategy with respect to their loan portfolios, thus limiting increases in risk weighted assets.

\section{Conclusions}

With a focus on examining the behavior of Australian banks' capital buffers, this study finds that capital buffers of large banks rises during economic upturns, while those of small banks fall in the same period. The behavior of large banks is attributed to the fact that they are accredited to use their own IRB approach to adjust the risk weights to lower the risk-weighted assets during good times, thus pushing the capital buffers up accordingly, while the level of capital level actually falls during this period. Given the current practice of Australian banks, the consideration of counter-cyclical bank regulations may be necessary to guarantee that capital buffers of all Australian banks will soar up during peak times and they should be driven by the increase in capital level.

Our results further suggest that banks with large total assets as a measure of bank size, a high ratio of risk-weighted assets to total assets, and high loan growth rates appear to hold lower capital buffers than other banks. In examining the effect of the latest global financial crisis, we uncover that banks tend to improve their capital position after crises.

\section{References}

Agénor, P-R., Alper, K., \& Pereira da Silva, L. (2012). Capital requirements and business cycles with credit market imperfections. Journal of Macroeconomics, 34, 687-705. http://dx.doi.org/10.1016/j.macro.2012.02.007

Ayuso, J., Pérez, D., \& Saurina, J. (2004). Are capital buffers pro-cyclical? Evidence from Spanish panel data, Journal of Financial Intermediation, 13, 249-264. http://dx.doi.org/10.1016/S1042-9573(03)00044-5

Blundell, R., \& Bond, S. (1998). Initial conditions and moment restrictions in dynamic panel data models. Journal of Econometrics, 87, 115-143. http://dx.doi.org/10.1016/S0304-4076(98)00009-8

Chen, Y. K., \& Hsu, C. L. (2013). Are Bank Capital Buffers Cyclical-Evidence for Developed and Developing Countries. http://www.tl.ntu.edu.tw/2012/asianfa2012/fullpaper/10316.pdf

Coffinet, J., Coudert, V., Pop, A., \& Pouvelle, C. (2012). Two-way interplays between capital buffers and credit growth: Evidence from French banks. Journal of International Financial Markets, Institutions and Money, 22, 1110-1125. http://dx.doi.org/10.1016/j.intfin.2012.05.011

Estrella, A. (2004). The Cyclical Behaviour of Optimal Bank Capital. Journal of Banking and Finance, 28, 1469-1498. http://dx.doi.org/10.1016/S0378-4266(03)00130-4

Fonseca, A. R., \& González, F. (2010). How bank capital buffers vary across countries. The influence of cost of deposits, market power and bank regulation. Journal of Banking and Finance, 34, 892-902. http://dx.doi.org/10.1016/j.jbankfin.2009.09.020

Francis, W. B., \& Osborne, M. (2012). Capital requirements and bank behavior in the UK: are there lessons for international capital standards?. Journal of Banking and Finance, 36, 803-816. http://dx.doi.org/10.1016/j.jbankfin.2011.09.011

García-Suaza, A. F., Gómez-González, J. E., Pabón A.M., \& Tenjo-Galarza, F. (2012). The cyclical behavior of bank capital buffers in an emerging economy: Size does matter. Economic Modelling, 29, 1612-1617.

Gorajek, A., \& Turner, G. (2010). Australian bank capital and the regulatory framework. RBA Bulletin, September Quarter 2010.

Guidara, A., Lai, V. S., Soumaré, I., \& Tchana, F. (2013). Banks' capital buffer, risk and performance in the Canadian banking system: Impact of business cycles and regulatory changes. Journal of Banking \& Finance, 37, 3373-3387. http://dx.doi.org/10.1016/j.jbankfin.2013.05.012 
Jackson, P. (1999). Capital Requirements and Bank Behaviour: The Impact of the Basel Accord. BCBS, Working Paper.

Jokipii, T., \& Milne, A. (2008). The cyclical behaviour of European bank capital buffers. Journal of Banking and Finance, 32, 1440-1451. http://dx.doi.org/10.1016/j.jbankfin.2007.12.001

Marcucci, J., \& Quagliariello, M. (2008). Is bank portfolio riskiness procyclical? Evidence from Italy using a vector autoregression. International Financial Markets, Institutions and Money, 18, 46-63. http://dx.doi.org/10.1016/j.intfin.2006.05.002

Milne, A. (2004). The Inventory Perspective on Bank Capital. http://papers.ssrn.com/sol3/papers.cfm?abstract_id=576062

Milne, A., \& Whalley, A. E. (2001). Bank Capital Regulation and Incentives for Risk-taking. http://papers.ssrn.com/sol3/papers.cfm?abstract_id=299319

Peura, S., \& Jokivuolle, E. (2004). Simulation Based Stress Tests of Banks' Regulatory Capital. Journal of Banking and Finance, 28, 1801-1824. http://dx.doi.org/10.1016/j.jbankfin.2003.05.005

Shim, J. (2013). Bank capital buffer and portfolio risk: The influence of business cycle and revenue diversification. Journal of Banking and Finance, 37, 761-772. http://dx.doi.org/10.1016/j.jbankfin.2012.10.002

Stolz, S., \& Wedow, M. (2011). Banks' regulatory capital buffer and the business cycle: evidence for Germany. Journal of Financial Stability, 7, 98-110. http://dx.doi.org/10.1016/j.jfs. 2009. 09.001

\section{(cc) $\mathrm{EY}$}

This work is licensed under a Creative Commons Attribution 3.0 License. 